Bul. Agrohorti 7(3): 271-280 (2019)

\title{
Teknik Perbanyakan Cepat Bibit Ubi Jalar (Ipomoea batatas L. Lam) dengan Perlakuan Rootone F dan Pupuk Daun.
}

\section{Application of Rootone F and Leaf Fertilizer on Rapid Multiplication Technique of Sweet Potato (Ipomoea batatas L. Lam) Cutting}

\author{
Haris Aprianto Setiawan, Asep Setiawan*, Megayani Sri Rahayu \\ Departemen Agronomi dan Hortikultura, Fakultas Pertanian, Institut Pertanian Bogor \\ (Bogor Agricultural University), Jl. Meranti, Kampus IPB Darmaga, Bogor 16680, Indonesia \\ Telp. \& Faks.62-251-8629353 e-mail agrohort@apps.ipb.ac.id \\ *Penulis Korespondensi : asetiawan_agh@yahoo.com
}

Disetujui : 21 Mei 2018 / Published Online September 2019

\begin{abstract}
The research aim was to obtain information on the effect of the Rootone $F$ and leaf fertilization for cutting production by means of rapid multiplication technique. The experiment was performed at the Experimental Field of Cikabayan Bawah IPB from August 2017 to November 2017. The experiment was arranged at Strip Plots in Randomized Block Design involving two treatments factor and three replications. The first factor was auxin concentration which consist of 4 levels, 0 ppm, 75 ppm, 150 ppm and 300 ppm. The second factor was application frequency of leaf fertilizer which consist of four levels namely, no fertilizer, 1 times/week, 1 times/ 2 week and 1 times/ 3 weeks. The results showed that there was interaction betweenauxin concentration and frequency of fertilizer application on primary branch length, number of primary branch leaves and number of primary branch cutting. The application frequency of fertilizer significantly affected the observed variable. The application of leaf fertilizer increased the number of node. Within two month rapid multiplication technique of sweet potato multiplication ratio was $1: 3$ for $15 \mathrm{~cm}$ cutting.
\end{abstract}

Keywords: fertilization, hormone, interaction, node, shoot stem

\begin{abstract}
ABSTRAK
Penelitian ini bertujuan untuk memperoleh informasi mengenai pengaruh dari Rootone $\mathrm{F}$ dan pemupukan daun terhadap produksi bibit dengan teknik perbanyakan cepat.Percobaan dilakukan di Kebun Percobaan Cikabayan Bawah, Dramaga, Bogor IPB pada bulan Agustus 2017 sampai Desember 2017.Percobaan disusun secara Split Blok dalam Rancangan Acak Kelompok melibatkan dua faktor perlakuan dan tiga ulangan.Faktor pertama adalah konsentrasi auksinyang terdiri dari empat taraf yaitu, 0 ppm, 150 ppm dan 300 ppm.Faktor kedua adalah frekuensi aplikasi pupuk daun yang terdiri dari empat taraf yaitu, tanpa pupuk, $1 \mathrm{kali} /$ minggu, $1 \mathrm{kali} / 2$ minggu dan $1 \mathrm{kali} / 3$ minggu.Hasil penelitian menunjukkan bahwa terdapat interaksi antara konsentrasi Rootone $\mathrm{F}$ dan frekuensi pemberian pupuk terhadap panjang cabang primer, jumlah daun cabang primer dan jumlah bibit cabang primer.Frekuensi pemberian pupuk berpengaruh nyata terhadap variabel pengamatan.Pemberian pupuk daun meningkatkan jumlah buku. Teknik perbanyakan cepat ubi jalar menghasilkan multiplikasi rasio 1:3 bibit ukuran $15 \mathrm{~cm}$ dalam waktu dua bulan.
\end{abstract}

Kata kunci : hormone, interaksi, mata tunas, pemupukan, setek pucuk 


\section{PENDAHULUAN}

Potensi dan manfaat ubi jalar (Ipomoea batatas L. Lam) sebagai bahan pangan alternatif sangatlah besar, terutama bagi upaya peningkatan gizi manusia, dan ketahanan pangan khususnya daerah pedesaan atau daerah terisolasi. Berdasarkan perhitungan analisis biaya, satu hektar lahan dengan patokan harga jual berkisar Rp 1,500 - 2,000 dapat diperoleh keuntungan bersih sebesar Rp 17 - 27 juta per musim tanam (UNDP, 2014).Permintaan ubi jalar yang tinggi di Indonesia belum dapat diimbangi dengan kapasitas produksi maksimumnya. Potensi produktivitas ubi jalar nasional dapat mencapai 30 ton $\mathrm{ha}^{-1}$ (Balitbang, 2012). Menurut data BPS (2016), dalam 10 tahun terakhir (2006-2015) produktivitas dan produksi ubi jalar mengalami peningkatan setiap tahunnya, akan tetapi luas lahan mengalami penurunan setiap tahunnya. Menurut Saleh et al. (2012) secara teknis produksi ubi jalar dapat ditingkatan dengan cara perluasan lahan. Selain luas lahan aspek penyediaan bibit juga merupakan hal penting dalam budidaya ubi jalar (Ardian, 2012).

Menurut Wargiono (2007) petani biasa memproduksi bibit ubi jalar dengan cara menanam satu bibit sumber berukuran $25-30 \mathrm{~cm}$, dan rata-rata mampu menghasilkan 4-6 bibit dalam waktu 2 bulan. Untuk luasan 1 ha dengan jarak tanam $75 \mathrm{~cm}$ x $30 \mathrm{~cm}$ membutuhkan bibit sebanyak $35 \quad 555$ setek ha ${ }^{-1}$ (Dipertan, 2016).Potensi sumber bibit ubi jalar yang dapat dihasilkan pada 2 bulan pertama sebanyak 18000 stek ha ${ }^{-1}$ (Fadjry et al., 2011). Upaya menghasilkan bibit secara lebih cepat dapat dilakukan dengan teknik rapid multiplication, yaitu menggunakan bibit dengan jumlah 2 atau 3 buku yang ditanam di bawah permukaan tanah (Wargiono et al., 2006). Teknik ini dapat mengurangi kebutuhan bibit sumber karena hanya dibutuhkan bibit dengan jumlah 2-3 buku dibanding cara konvensional yang biasanya menggunakan 5-7 buku. Berdasarkan penelitian Maulida (2016), penanaman setek ubi jalar dengan jumlah buku 3, 4, dan 5 menghasilkan bobot umbi total yang tidak berbeda nyata.

Menurut Suprapto (2004), pada perbanyakan dengan cara setek, tunas akan terbentuk dan tumbuh setelah akar terbentuk dengan baik. Danu dan Pramono (2004) menyebutkan bahwa salah satu faktor yang mempengaruhi keberhasilan setek adalah zat pengatur tumbuh (ZPT).Rootone- $F$ merupakan salah satu merek dagang dari ZPT yang mengandung auksin.Auksin mengandung senyawa Indole 3-butiric acid (IBA) (0.057\%), 2metil 1-naphtalene-acetic acid (MNAA) (0.003\%), 1-naphtalene-acetamide (NAD)
(0.067\%), 2-metil naphtalene-acticamide $(0.013 \%)$, dan thiram (4\%) yang dapat mempercepat dan memperbanyak perakaran setek (Manurung, 1987). Selain ZPT, setek perlu diberikan tambahan unsur hara makro dan mikro berupa pupuk untuk menunjang pertumbuhan serta mempercepat perkembangan tunas dan daun. Salah satu pupuk yang sering digunakan untuk tanaman adalah pupuk daun.Pemupukan lewat daun lebih cepat penyerapan haranya jika dibandingkan pemupukan lewat akar (Lingga, 1998).

Pengaruh terbaik terhadap pertambahan panjang akar tanaman cabai jamu (Piper retrofractum Vahl.) terdapat pada tarafkonsentrasi ZPT auksin 300 ppm sedangkan untuk jumlah ruas terdapat pada konsentrasi 200 ppm (Budianto et al., 2013). Menurut Purnamasari (2013), semakin tinggi konsentrasi ZPT auksinyang diberikan pada tanaman Arachis pintoi pertumbuhannyaakan semakin cepat.Pada penelitian Uluputty (2015) aplikasi pupuk daun (20:15:15) dengan konsentrasi $2 \mathrm{gl}^{-1}$ pada tanaman seledri, mampu memberikan respon terbaik untuk tinggi tanaman, jumlah anakan, jumlah daun dan bobot segar tajuk, sedangkan menurut Palemba (2012), aplikasi pupuk daun (20:15:15) pada tanaman jabon respon terbaik untuk tinggi tanaman, jumlah daun, diameter batang, dan berat kering tajuk ditunjukkan pada konsentrasi $2 \mathrm{gl}^{-1}$.

Keefektifan pemupukan agar tanaman dapat tumbuh dengan optimal dipengaruhi oleh lima tepat yaitu tepat waktu, tepat dosis, tepat cara, tepat jenis, dan tepat tempat (Simatupang, 2010). Menurut Poerwanto dan Susila (2014) dosis dan waktu pemberian pupuk perlu ditentukan dengan tepat, agar kebutuhan tanaman terpenuhi, kesuburan tanah dapat dipertahankan, kehilangan hara dari tanah dapat diminimalkan, serta pencemaran tanah dan air dapat diminimalkan. Pemberian pupuk daun dengan selang waktu 2-4 minggu, baik bagi pertumbuhan setek teh (Bintoro et al.,1994). Penelitian ini dilakukan dengan tujuan untuk mempelajari pertumbuhan dan produksi bibit yang berasal dari setek pucuk ubi jalar dengan teknik perbanyakan cepat yang diberi tambahan ZPT dan pupuk daun pada frekuensi pemupukan yang berbeda.

\section{BAHAN DAN METODE}

Penelitian dilakukan pada bulan Agustus sampai November 2017. Penanaman dilaksanakan di Kebun Percobaan Cikabayan Bawah, Dramaga, Bogor Institut Pertanian Bogor. Pengukuran dan penimbangan dilaksanakan di Laboratorium Pemuliaan Tanaman IPB.Bahan yang digunakan adalah setek pucuk ubi jalar 
varietas Beta 1 umur 2 bulan ukuran $25 \mathrm{~cm}$, fungisida Antracol, ZPT Rootone-F, pupuk daun Gandasil D (20:15:15). Media perakaran yang digunakan adalah campuran tanah, kompos, dan pasir dengan perbandingan 1:2:0.5. Alat yang digunakan seperti, mistar ukur, ember plastik, sungkup plastik, kamera, pot, autoclave, alat timbangan analitik, gelas ukur, gunting, ayakan, hand sprayer, sekat, paranet dan alat tulis.

Penelitian dilakukan dengan menggunakan Rancangan Acak Kelompok Petak Terbagi (RAK Split-Blok) diulang 3 kali.Perlakuan terdiri atas dua faktor yaitu konsentrasi ZPT auksin dan frekuensi pemberian pupuk daun. Faktor pertama adalah konsentrasi ZPT auksin yang terdiri atas 4 taraf, 0 ppm (R0), 75 ppm (R1), 150 ppm (R2) dan $300 \mathrm{ppm}$ (R3). Faktor kedua adalah pemberian pupuk daun yang terdiri atas 4 taraf, yaitu tanpa pupuk (P0), pemberian pupuk daun 1 minggu sekali (P1), pupuk daun 2 minggu sekali (P1) dan pupuk daun 3 minggu sekali (P3). Terdapat 16 kombinasi perlakuan dan masingmasing diulang sebanyak 3 kali sehingga terdapat 48 unit percobaan.Setiap unit percobaan terdiri atas 5 setek sehingga membutuhkan 240 setek ubi jalar. Data yang diperoleh dianalisis dengan metode sidik ragam sesuai dengan rancangan yang digunakan untuk mengetahui tingkat signifikansi interaksi dan pengaruh faktor tunggal perlakuan konsentrasi danfrekuensi pemberian pupuk daun, terhadap pertumbuhan setek ubi jalar. Uji ragam dilakukan dengan uji $F$ menggunakan aplikasi SAS (Statistical Analysis System). Jika terdapat perbedaan antar perlakuan dilanjutkan dengan uji lanjutan menggunakan Duncan's Multiple Range Test (DMRT) pada taraf 5\%.

Bahan tanam atau setek diperoleh dari plasma nutfah kebun percobaan Leuwikopo. Media tanam yang digunakan dalam penelitian ini yaitu campuran media tanah, pupuk kompos dan pasir dengan perbandingan 1:2:0.5 (FAO, 2010). Media pasir dan tanah disetrilisasi dengan autoclave dengan tekanan $2 \mathrm{~atm} / 15$ psi (pounds pe square inch) pada suhu $121^{\circ} \mathrm{C}$ selama 15 menit (Marino and Benjamin, 1986), kemudian dicampur dengan kompos dan dipindah ke wadah pot. Sebelum media digunakan untuk penanaman, dilakukan pengecekan kadar $\mathrm{pH}$ dengan $\mathrm{pH}$ meter dan $\mathrm{pH}$ indicator strips. Pada lahan penelitian dibuat naungan yang terbuat dari paranet (65\%) dengan ketinggian 3 meter. Larutan ZPTauksin $75 \mathrm{ppm}, 150 \mathrm{ppm}$, dan $300 \mathrm{ppm}$, dibuat dengan melarutkan $0.75 \mathrm{~g}, \quad 1.5 \mathrm{~g}$, dan $3 \mathrm{~g}$ ZPT auksinmasing-masingdalam $10000 \mathrm{ml}$ air. Sedangkan dosis pupuk daun yang digunakan $2 \mathrm{~g}$ $1^{-1}$. Larutan stok pupuk daun dibuat dengan cara menimbang pupuk daun sebanyak $200 \mathrm{~g}$ kemudian dilarutkan dalam 1 liter air. Pada saat akan dipergunakan untuk pemupukan, larutan stok tersebut diambil $10 \mathrm{ml}$, kemudian diencerkan dengan cara menambah air sampai 1 liter.

Cabang ubi jalar yang akan digunakan dipotong sepanjang $25 \mathrm{~cm}$ dari bagian pucuk, dengan potongan miring $\left( \pm 45^{\circ}\right)$, setek kemudian dipotong setiap 2 buku(mata tunas) dengan menyisakan 1 daun. Setiap satu setek diambil 2 potongan, kemudian direndam dengan fungisida Antracol selama 15 menit.Setelah itu bagian pangkal setek direndam pada larutan ZPT auksinsesuaidengan perlakuan selama 15 menit. Setelah direndam dalam larutan ZPT auksinsetek kemudian ditanam dalam pot dengan ketentuan 1 berada di dalam media tanam dan 1 buku berada di atas permukaan media tanam dengan menyisakan 1 helai daun saja. Pada pot juga ditaburkan insektisida Furadan.Untuk perlakuan kontrol, bahan tanam langsung ditanam pada pot. Penyemprotan pupuk daun dilakukan dengan 3 frekuensi waktu yaitu setiap 1 minggu sekali, 2 minggu dan 3 minggu sekali. Masing-masing perlakuan pemupukan dimulai saat 7 HST sampai 77 HST. Pemupukan dilakukan dengan cara menyemprotkan larutan sebanyak $25 \mathrm{ml} /$ tanaman untuk seluruh perlakuan, secara merata sampai tajuk tanaman basah, menggunakan alat hand sprayer. Pemeliharaan setek berupa penyiraman yang dilakukan setiap 1 hari sekali. Penyemprotan fungisida Antracol dengan konsentrasi $2 \quad \mathrm{~g} \quad \mathrm{l}^{-1}$ dilakukan pada awal penanaman sampai 7 HST.Pemotongan daun batang utama dilakukan setelah tanaman berumur 28 HST. Apabila terdapat gejala serangan hama langsung dilakukan tindakan pengendalian secara mekanis. Panen bibitcabang primer dilakukan saat tanaman ubi jalar berumur 2 bulan (56 HST).

Pengamatan dikelompokkan menjadi 3 yaitu pengamatan akar, pengamatan vegetatif, dan pengamatan komponen produksi bibit.Pengamatan akar meliputi jumlah dan panjang akar.Pengamatan vegetatifpanjang cabang dan jumlah daun cabang primer, jumlah cabang sekunder dan jumlah buku cabang primer.Pengamatan komponen produksi bibit meliputijumlah panen bibit cabang primer ukuran $15 \mathrm{~cm}$.

\section{HASIL DAN PEMBAHASAN}

\section{Kondisi Umum}

Penelitian dilakukan ketika musim penghujan dengan suhu rata-rata $21,7{ }^{\circ} \mathrm{C}$, curah hujan rata-rata yaitu $467 \mathrm{~mm}$ bulan $^{-1}$ dan kelembaban rata-rata $83 \%$. Media tanam yang digunakan mempunyai kadar $\mathrm{pH}$ 6.5. Kondisi lingkungan sudah sesuai dengan syarat tumbuh ubi jalar.Daerah dengan dengan ketinggian hingga $1500 \mathrm{~m}$ dpl (dari permukaan laut) dengan $\mathrm{pH}$ tanah 5.5-7.5, distribusi hujan pada kisaran 
750-1500 mm per tahun, suhu rata-rata sekitar 21-25 ${ }^{\circ} \mathrm{C}$, dan kelembaban (RH) berkisar $60-70$ persen akan cukup bagus bagi pertumbuhan ubi jalar (Distantp, 2012).

Secara visual pertumbuhan tanaman sangat baik.Batang ubi jalar tumbuh tegak dan mulai menjalar pada 35 HST.Presentase tumbuh setek sangat baik, mencapai $100 \%$, yang artinya semua tanaman tumbuh dan hidup sampai akhir pengamatan.Daya tumbuh yang baik tersebut didukung oleh perlakuan sterilisasi media tanam pasir dan tanah menggunakan autoclave dan pemasangan paranet. Proses sterilisasi mampu menekan serangan penyakit tanaman yang disebabkan oleh virus, bakteri dan cendawan.Menurut Hartmann dan Kester (1983), kisaran suhu yang baik untuk pembentukan perakaran pada setek adalah $21-27{ }^{\circ} \mathrm{C}$. Intensitas cahaya yang masuk ke dalam sungkup dengan naungan $70 \%$ adalah $1000-7000$ klux (Puspitaningrum, 2014). Menurut Widodo dan Sudradjat (1984) pembibitan dengan metode setek tanpa naungan dan intensitas cahaya matahari yang kuat menyebabkan setek layu bahkan terbakar, terutama setek muda. Manipulasi tempat pembibitan dengan naungan paranet $65 \%$ dapat mengatasi masalah intensitas cahaya matahari.

Penyemprotan fungisida dilakukan untuk mencegah serangan cendawan Pythium, dan Fusarium.Gulma yang tumbuh pada media pot didominasi jenis rumput Rotboelia exaltata. Gulma tersebut tumbuh dari biji yang terbawa angin dari gulma yang ada disekitar tempat percobaan.Hama yang menyerang tanaman antara lain ulat jengkal (Geometridae sp.), ulat bulu (Macrothylacia rubi), belalang (Valanga sp.), penggerek batang (Omphisia anastomasalis), kepik (Physomerus grossipes) dan kumbang boleng (Cylas formicarius). Hama penggerek batang merupakan hama yang menimbulkan kerusakan tanaman yang cukup parah, yaitu seperti patah cabang akibat gerekan pada bagian dalam batang. Hama penggerek batang mulai terlihat pada 3 MST. Menurut Rukmana (2007) gejala serangan hama penggerek batang adalah terjadi pembengkakan batang, beberapa bagian batang mudah patah, daun-daun menjadi layu, dan akhirnya cabang tanaman akan mati.

Rata-rata jumlah tunas yang tumbuh yaitu 1,2 buah, artinya beberapa mata tunas yang tertimbun di dalam tanah mampu tumbuh dan berkembang menjadi cabang primer. Pada pengamatan kecepatan tumbuh akar yang dilakukan saat 2 HST, 57\% akar telah mucul denganrata - rata jumlah akar sebanyak 2 akar/bibit dan panjang rata - rataya 0.23 $\mathrm{cm}$.Penyiraman tanaman dilakukan 2 kali sehari saat pagi dan sore.Penyiraman tambahan juga dilakukan ketika cuaca cerah dengan intensitas sinar matahari yang tinggi selama 2 hari berturutturut. Peningkatan intensitas penyiraman dilakukan untuk mencegah media pot mengalami kekeringan.

Tabel 1.Rekapitulasi hasil sidik ragam komponen pertumbuhan setek ubi jalar.

\begin{tabular}{|c|c|c|c|c|c|}
\hline \multirow[b]{2}{*}{ Peubah Pengamatan } & \multicolumn{3}{|c|}{ ZPT auksin } & \multirow[b]{2}{*}{$\mathrm{RxP}$} & \multirow{2}{*}{$\begin{array}{l}\mathrm{KK} \\
(\%)\end{array}$} \\
\hline & Umur (HST) & $(\mathrm{R})$ & Pupuk Daun (P) & & \\
\hline Jumlah akar & 2 & tn & - & - & 37.90 \\
\hline Panjang akar & 2 & tn & - & - & 12.91 \\
\hline \multirow[t]{4}{*}{ Panjang cabang primer } & 14 & $\operatorname{tn}$ & tn & tn & 9.70 \\
\hline & 28 & tn & $* *$ & $*$ & 6.66 \\
\hline & 42 & $*$ & $* *$ & $\operatorname{tn}$ & 6.13 \\
\hline & 56 & $*$ & $* *$ & th & 8.10 \\
\hline \multirow[t]{4}{*}{ Jumlah daun cabang primer } & 14 & $*$ & tn & $\operatorname{tn}$ & 13.14 \\
\hline & 28 & tn & $*$ & $*$ & 6.35 \\
\hline & 42 & $*$ & tn & $\operatorname{tn}$ & 6.09 \\
\hline & 56 & $*$ & $*$ & $*$ & 5.96 \\
\hline Jumlah tunas cabang & 14 & - & - & - & 0 \\
\hline \multirow[t]{3}{*}{ sekunder } & 28 & - & - & - & 0 \\
\hline & 42 & tn & $* *$ & $\operatorname{tn}$ & 14.69 \\
\hline & 56 & tn & $*$ & $\operatorname{tn}$ & 21.79 \\
\hline Jumlah buku cabang primer & 56 & tn & $* *$ & tn & 5.83 \\
\hline Jumlah bibitcabang primer & 56 & $*$ & $* *$ & $*$ & 6.76 \\
\hline Bobot basah cabang primer & 56 & tn & $*$ & $\operatorname{tn}$ & 9.24 \\
\hline Bobot kering cabang primer & 56 & tn & $*$ & $\operatorname{tn}$ & 8.88 \\
\hline
\end{tabular}

HST : hari setelah tanam, R: konsentrasi ZPT auksin; P: frekuensi pemupukan pupuk daun; *: berpengaruh nyata pada taraf kepercayaan $95 \%$; ** : berpengaruh sangat nyata pada taraf kepercayaan $95 \%$. t) transformasi data dengan $\sqrt{x+1}$ 
Rekapitulasi sidik ragam pengaruh konsentrasi ZPT auksin, frekuensi pemupukan, dan interaksi antara keduanya terhadap pertumbuhan vegetatif, hasil panen bibit, bobot basah, bobot kering dan jumlah akar disajikan pada Tabel 1. Nilai KK tertinggi terdapat pada peubah jumlah akar pada umur 2 MST yaitu $37.9 \%$ dan KK terendah diperoleh pada peubah jumlah buku cabang primer umur 56 HST yaitu sebesar $5.83 \%$. Nilai KK menunjukkan tingkat ketepatan pada perlakuan yang diperbandingkan dan merupakan indek.Hanafiah (2005) menyatakan bahwa nilai KK untuk percobaan laboratorium maksimal $20 \%$ dan untuk percobaan lapangan maksimal $40 \%$.

\section{Evaluasi Terhadap Karakter Vegetatif}

\section{Jumlah dan Panjang Akar}

Hasil percobaan menunjukkan bahwa tidak terdapat pengaruh yang nyata dari perlakuan konsentrasi ZPT auksin terhadap peubah panjang akar dan jumlah akar pada umur 2 HST (Tabel 1).Peubah jumlah akarpada Tabel 2 menunjukkan bahwa R2 dengan konsentrasi ZPT auksin 150 ppm merupakan perlakuan dengan jumlah akar yang tertinggi diantara perlakuan lainnya.Sedangkan pada peubah panjang akar, perlakuan R1 dengan konsentrasi ZPT auksin terendah yaitu $75 \mathrm{ppm}$ menghasilkan panjang akar tertinggi.Bibit yang tidak diberi perlakuan ZPT auksin (R0) memiliki panjang akar yang paling pendek dibandingkan bibit yang diberikan perlakuan ZPT auksin.Hal ini disebabkan oleh pengaruh ZPT auksin, yang berfungsi dalam inisiasi dan pemanjangan akar sehingga bibit yang tidak mendapat perlakuan ZPT auksin cenderung lebih kecil pertambahan panjang akarnya (Harjadi 2009).KonsentrasiZPT auksin tidak berpengaruh nyata. Hal ini diduga karena kadar konsentrasi yang diberikan terlalu sedikit atau kadar ZPT auksin dalam batang sudah mencukupi untuk pertumbuhan akar yang optimal pada umur 2 HST.Tabel 2. Pengaruh konsentrasi ZPT auksin terhadap pertumbuhan akar pada setek umur 2 HST.

\section{Jumlah Daun Cabang Primer}

Pada Gambar 1 terlihat bahwa perlakuan tanpa ZPT auksin cenderung mengalami penurunan pada semua frekuensi pemupukan yaitu pada P1R0, P2R0 dan P3R0. Kombinasi perlakuan P1R2 menghasilkan jumlah daun umur 28 HST tertinggi, namun tidak berbeda nyata dengan P0R0, P1R3 dan P2R3.Meskipun kombinasi perlakuan P1R2 jumlah daun umur 28 HST tertinggi, namun dengan konsentrasi ZPT auksinyang sama $(\mathrm{R} 2=150 \mathrm{ppm})$ mengalami penurunan jumlah daun yang cukup drastis pada frekuensi pemupukan 2 minggu sekali (P2R2).Grafik pada Gambar 1 menunjukkan bahwa terdapat interaksi antara konsentrasi ZPT auksindan frekuensi pemupukan.Pada R0 dan R1 perlakuan $P$ (pada semua taraf) tidak memberikan pengaruh yang nyata terhadap perubahan jumlah daun cabang primer umur 28 HST. Peningkatan jumlah daun yang signifikan terjadi pada $\mathrm{R} 2$ dan R3 perlakuan P1, namun pada P2 terjadi penurunan jumlah daun yang nyata pada perlakuan R2 sedangkan pada R3 tidak terjadi perubahan jumlah daun. Pada perlakuan P3 hanya pada R3 yang mengalami penurunan jumlah daun signifikan.

Tabel 2. Pertumbuhan akar vegetatif

\begin{tabular}{ccc}
\hline \multirow{2}{*}{ Perlakuan } & \multicolumn{2}{c}{ Pertumbuhan Akar } \\
\cline { 2 - 3 } & $\begin{array}{c}\text { Jumlah akar } \\
\text { (buah) }\end{array}$ & $\begin{array}{c}\text { Panjang akar } \\
(\mathrm{cm})\end{array}$ \\
\hline R0 & 2.69 & 0.33 \\
R1 & 2.67 & 0.44 \\
R2 & 3.01 & 0.43 \\
R3 & 2.68 & 0.35 \\
\hline Keterangan & $\begin{array}{c}\text { R0= } 0 \\
\text { ppm, R1= 75 }\end{array}$ & ppm, R2= 150 \\
& ppm,R3= 300 ppm. *Angka yang diikuti \\
& huruf yang sama pada kolom yang sama \\
& menunjukkan tidak berbeda nyata pada \\
& uji DMRT 5\%
\end{tabular}

Pada setek umur 56 HST kombinasi perlakuan yang menghasilkan jumlah daun tertinggi terdapat pada P2R3 namun tidak berbeda nyata hampir pada semua kombinasi perlakuan, kecuali pada P0R2, P0R1, P1R2, P2R1 dan P3R0.Terdapat interaksi antar perlakuan pada peubah jumlah daun umur 56 HST (Gambar 1).Pada R0, R2 dan R3 perlakuan $\mathrm{P}$ (pada semua taraf) tidak memberikan pengaruh yang nyata terhadap perubahan jumlah daun cabang primer umur 56 HST. Peningkatan jumlah daun yang signifikan hanya terjadi pada R1 perlakuan P3, sedangkan perlakuan lain cenderung mengalami penurunan.

Peningkatan jumlah daun dipengaruhi oleh adanya nitrogen yang terkandung dalam pupuk daun. Menurut Ying-Tung (2007) nitrogen berpengaruh lebih besar terhadap pertambahan jumlah daun dibandingkan fosfor dan kalium.Hasil penelitian Nurholis (2014) menyatakan bahwa setek vanili dengan frekuensi pemupukan 3 hari sekail mempunyai jumlah daun yang paling banyak sampai 10 MSP, dibandingkan pemupukan 6 hari sekali. Salah satu hormon yang dikandung Rootone-Fadalah IBA.Menurut Latifah (2005), penggunaan hormon tumbuh IBA mempunyai beberapa 
keunggulan karena zat tumbuh IBA yang diberikan dapat berfungsi dengan baik hingga memungkinkan terbentuknya klorofil pada daun.

Konsentrasi ZPT auksin dan frekuensi pemupukan dapat saling berinteraksi atau berdiri sendiri dalam mempengaruhi peubah pengamatan. Gomez dan Gomez (1995) mengemukakan bahwa dua faktor perlakuan dikatakan berinteraksi apabila pengaruh suatu faktor perlakuan berubah pada saat perubahan taraf faktor perlakuan lainnya. Selanjutnya dinyatakan oleh Steel dan Torrie (1991) bahwa bila pengaruh interaksi berbeda tidak nyata, maka disimpulkan bahwa diantara faktor-faktor perlakuan tersebut bertindak bebas atau pengaruhnya berdiri sendiri.
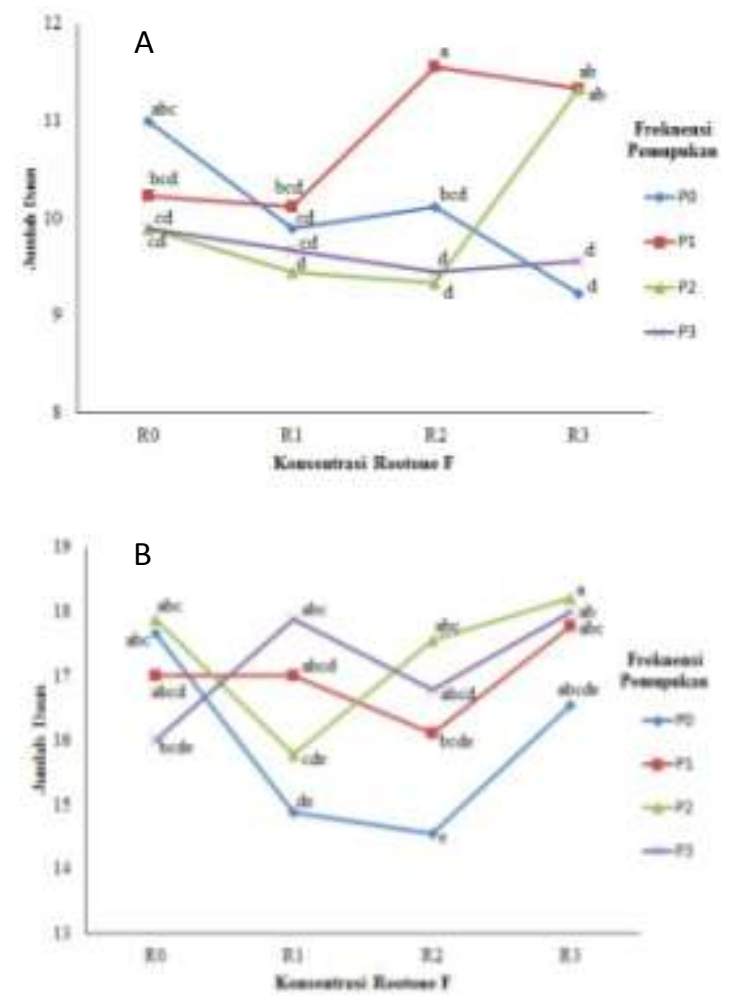

Keterangan $: \mathrm{P} 0=$ tanpa pupuk, $\mathrm{P} 1=1$ Minggu sekali, $\mathrm{P} 2=2$ minggu sekali, $\mathrm{P} 3=3$ minggu sekali, $\mathrm{R} 0=0 \mathrm{ppm}, \mathrm{R} 1=75$ ppm R2= 150 ppm, R3= 300 ppm. *Simbol yang diikuti huruf yang sama pada masing - masing grafik menunjukkan tidak berbeda nyata pada uji DMRT 5\%

Gambar 1. Interaksi perlakuan konsentrasiZPT auksindan frekuensi pemupukan pupuk daun terhadap jumlah daun pada umur setek (a) 28 HST dan (b) 56 HST.

\section{Panjang Cabang Primer}

Gambar 2 menunjukkan bahwa pada umur setek 28 HST kombinasi perlakuan dengan nilai panjang cabang primer tertinggi terdapat pada perlakuan P1R3, namun tidak berbeda nyata dengan perlakuan P1R2 dan P2R3. Berdasarkan uji lanjut interaksi antara konsentrasi ZPT auksindan frekuensi pemupukan setek umur 28 HST, dapat diketahui pula bahwa panjang cabang primer dengan nilai tertinggi terdapat pada perlakuan dengan frekuensi pemupukan yang paling sering yaitu 1 minggu sekali dengan konsentrasi ZPT auksin yang paling banyak sebesar 300 ppm (P1R3).

Grafik pada Gambar 2 menunjukkan adanya interaksi antar perlakuan.Pada grafik tersebut dapat dilihat bahwa R0 dan R1 pada semua taraf perlakuan $\mathrm{P}$ tidak memberikan perubahan panjang cabang primer umur 28 HST.Peningkatan panjang cabang signifikan terjadi pada R2 dan R3 perlakuan P1, namun R2 mengalami penurunan signifikan pada perlakuan P2 sedangkan pada R3 penurunan yang terjadi tidak nyata.

Pemberian pupuk daun pada frekuensi tertentu sangat mempengaruhi pertumbuhan panjang cabang primer ubi jalar. Hal tersebut sesuai dengan penelitian Shofiana (2015), pemberian pupuk daun 1 minggu sekali dengan konsentrasi 2 dan 3 g 1-1 pupuk daun pada tanaman cabai hias, menghasilkan tinggi tanaman tanpa pupuk daun.Berdasarkan data pengamatan panjang cabang primer, panen bibt ubi jalar dapat dilakukan paling cepat pada umur 28HST dengan ukuran setek rata-rata $15 \mathrm{~cm}$.

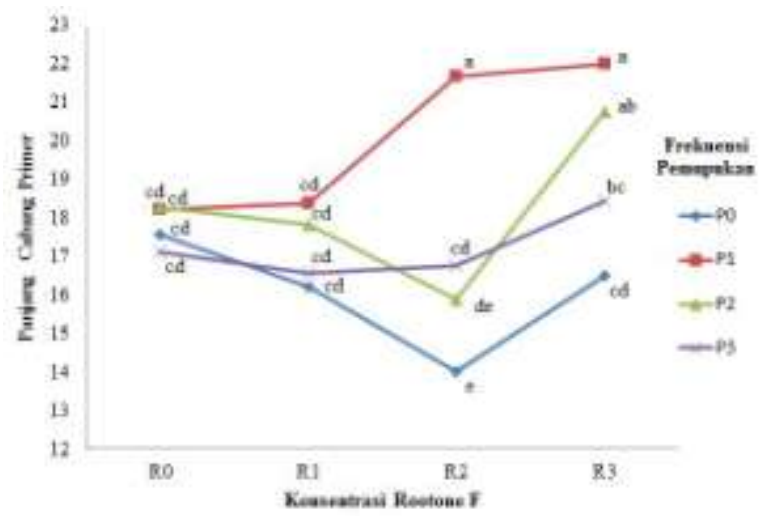

Keterangan : $\mathrm{P} 0=$ tanpa pupuk, $\mathrm{P} 1=1$ Minggu sekali, $\mathrm{P} 2=2$ minggu sekali, $\mathrm{P} 3=3$ minggu sekali, $\mathrm{R} 0=0 \mathrm{ppm}, \mathrm{R} 1=75$ ppmR2 $=150$ ppm, R3 $=300$ ppm.*Simbol yang diikuti huruf yang sama pada masing - masing grafik menunjukkan tidak berbeda nyata pada uji DMRT 5\%

Gambar 2. Interaksi perlakuan konsentrasiZPT auksindan frekuensi pemupukan pupuk daun terhadap panjang cabang primer pada umur setek $28 \mathrm{HST}$.

\section{Jumlah Cabang Sekunder}

Cabang sekunder adalah mata tunas yang tumbuh dari cabang primer. Berdasarkan 
pengamatan di lapang cabang sekunder pada ubi jalar muncul pada saat umur 42 HST.Lamanya waktu yang dibutuhkan cabang sekunder untuk tumbuh menandakan adanya dominansi apikal dari cabang primer.Tidak terdapat interaksi antara frekuensi pemupukan dan konsentrasi ZPT auksinterhadap peubah jumlah cabang sekunder (Tabel 1).Jumlah cabang sekunder nyatadipengaruhi oleh faktor tunggal frekuensi pemupukan.

Hasil uji lanjut faktor frekuensi pemupukan yang ada pada Tabel 3 diketahui bahwa perlakuan pemupukan 1 minggu sekali (P1) pada saat setek berumur 42 HST adalah perlakuan yang terbaik untuk peubah jumlah cabang sekunder. Pada umur 56 HST perlakuan P1 masih tetap yang tertinggi namun tidak berbeda nyata dengan P3. Berdasarkan data tersebut diketahui pula bahwa tunas cabang sekunder yang muncul maksimal berjumlah 1 tunas. Pertumbuhan cabang sekunder diduga salah satunya disebabkan oleh meningkatnya serapan $\mathrm{P}$ yang terdapat pada pupuk daun. Serapan P dalam bentuk tersedia oleh tanaman dapat meningkatkan pembelahan sel (Leiwakabessy dan Sutandi 2004), sehingga tanaman yang dipupuk dapat membentuk tunas cabang baru lebih banyak dibandingkan dengan tanaman yang tidak dipupuk.

Tabel 3.Jumlah cabang sekunder ubi jalar pada panen pertama.

\begin{tabular}{ccccc}
\hline \multirow{2}{*}{ Perlakuan } & \multicolumn{4}{c}{ Hari Setelah Tanam (HST) } \\
\cline { 2 - 5 } & 14 & 28 & 42 & 56 \\
\hline P0 & 0 & 0 & $0.00 \mathrm{~b}$ & $0.36 \mathrm{c}$ \\
P1 & 0 & 0 & $1.27 \mathrm{a}$ & $0.97 \mathrm{a}$ \\
P2 & 0 & 0 & $0.75 \mathrm{~b}$ & $0.56 \mathrm{bc}$ \\
P3 & 0 & 0 & $0.75 \mathrm{~b}$ & $0.81 \mathrm{ab}$ \\
\hline Keterangan : P0= tanpa pupuk, P1= 1 Minggu sekali, \\
\\
P2= 2 minggu sekali,P3= 3 minggu \\
sekali. *Angka yang diikuti huruf yang \\
sama pada kolom yang sama \\
menunjukkan tidak berbeda nyata pada \\
uji DMRT 5\%.
\end{tabular}

\section{Bobot Basah dan Bobot Kering Cabang Primer}

Berdasarkan hasil sidik ragam pada Tabel 1, hanya perlakuan frekuensi pemupukan yang berpengaruh terhadap peubah bobot basah dan bobot kering cabang primer. Hasil uji lanjut pada Tabel 5, diketahui bahwa perlakuan P1 merupakan perlakuan faktor tunggal frekuensi pemupukan dengan hasil bobot basah dan bobot kering cabang primer tertinggi. Perlakuan pada semua frekuensi pemupukan (P1, P2 dan P3) berpengaruh nyata terhadap bobot kering cabang primer dibandingkan perlakuan tanpa pemupukan
(P0). Pertumbuhan vegetatif tanaman sangat mempengaruhi bobot basah dan kering cabang primer.Apabila pertumbuhan panjang cabang primer mengalami peningkatan, maka berat basah dan kering bagian pucuk juga meningkat.

Berat kering tanaman merupakan indikator yang umum digunakan untuk mengetahui baik atau tidaknya pertumbuhan bibit, karena berat kering tanaman dapat menggambarkan efisiensi proses fisiologis di dalam tanaman yaitu proses fotosintesis, respirasi, translokasi dan penyerapan air serta mineral (Handayani 2009). Pada penelitian ini pemberian pupuk daun berpengaruh nyata terhadap peningkatan bobot kering cabang primer.

Tabel 5.Pengaruh frekuensi pemupukan terhadap bobot basah dan bobot kering cabang primer.

\begin{tabular}{ccr}
\hline Perlakuan & $\begin{array}{c}\text { Bobot Basah } \\
\text { Cabang Primer } \\
(\mathrm{g})\end{array}$ & $\begin{array}{r}\text { Bobot Ke } \\
\text { Cabang Prim }\end{array}$ \\
\hline P0 & $19.03 \mathrm{c}$ & $2.38 \mathrm{~b}$ \\
P1 & $26.78 \mathrm{a}$ & $3.09 \mathrm{a}$ \\
P2 & $22.36 \mathrm{bc}$ & $2.90 \mathrm{a}$ \\
P3 & $24.50 \mathrm{ab}$ & $3.09 \mathrm{a}$
\end{tabular}

Keterangan : $\mathrm{P} 0=$ tanpa pupuk, $\mathrm{P} 1=1$ Minggu sekali, $\mathrm{P} 2=2$ minggu sekali, $\mathrm{P} 3=3$ minggu sekali. *Angka yang diikuti huruf yang sama pada kolom yang sama menunjukkan tidak berbeda nyata pada uji DMRT 5\%.

\section{Evaluasi Terhadap Komponen Produksi \\ Jumlah Bibit dan Jumlah Buku Cabang Primer}

Data dari peubah jumlah bibitcabang primer didapatkan dengan memotongkeseluruhan cabang primer yang dapat dipanen pada umur 56 HST.Hasil sidik ragam peubah jumlah bibitcabang primer menunjukkan bahwa terdapat pengaruh yang nyata dari faktor tunggal perlakuan konsentrasi ZPT auksindan frekuensi pemupukan (Tabel 1).

Tabel 4 menunjukkan bahwa jumlah tertinggi dari pengaruh faktor tunggal frekuensi pemupukan terhadap jumlah bibit cabang primer ukuran $15 \mathrm{~cm}$, yaitu perlakuan pemupukan 1 minggu sekali P1,namun tidak berbeda nyata dengan P3. Pengaruh faktor tunggal konsentrasi ZPT auksin pada R3menghasilkan jumlah tertinggi bibit cabang primer ukuran $15 \mathrm{~cm}$ walaupun tidak berbeda nyata dengan perlakuan R2.Panen bibit cabang primer pada umur 56 HST rata-rata menghasilkan 3 bibitukuran $15 \mathrm{~cm}$, sehingga apabila terdapat setek pucuk dengan 
jumlah buku 8 maka dengan teknik perbanyakan cepat setek 2 buku dapat menghasilkan 12 bibitukuran $15 \mathrm{~cm}$. Hasil penelitian Maulida (2016), menyebutkan bahwa jumlah buku perlakuan 3 buku , 4 buku, dan 5 buku tidak berpengaruh terhadap jumlah bibit ukuran $25 \mathrm{~cm}$, $20 \mathrm{~cm}$, dan $15 \mathrm{~cm}$.

Grafik interaksi pada Gambar 3 menunjukkan bahwa jumlah tertinggi bibit ukuran $15 \mathrm{~cm}$ terdapat pada kombinasi perlakuan P3R1. Grafik interaksi tersebut menggambarkan pola yang hampir sama pada semua kombinasi perlakuan. Perlakuan konsentrasi ZPT auksin pada semua taraf mengalami peningkatan jumlah bibitpada pemupukan 1 minggu sekali, kemudian mengalami penurunan jumlah pada pemupukan 2 minggu sekali dan kembali meningkat pada pemupukan 3 minggu sekali.

Berdasarkan Tabel 1, terdapat interaksi antar perlakuan yang mempengaruhi peubah jumlah bibit ukuran $15 \mathrm{~cm}$. Hasil uji lanjut interaksi antar perlakuan padaGambar 3 dapat dilihat bahwa terjadi peningkatan signifikan jumlah bibit ukuran $15 \mathrm{~cm}$ pada $\mathrm{R}$ (semua taraf) perlakuan P1. Penurunan jumlah bibit signifikan hanya terjadi pada R0 perlakuan P2, kemudian terjadi peningkatan jumlah signifikan kembali pada perlakuan P3 sedangkan perlakuan lainnya tidak mengalami perubahan jumlah bibit yang nyata.

Tabel 4.Pengaruh faktor tunggal terhadap jumlah bibit ukuran $15 \mathrm{~cm}$ dan jumlah buku cabang primer umur 56 HST.

\begin{tabular}{ccc}
\hline Perlakuan & Jumlah Bibit & Jumlah Buku \\
\hline Frekuensi & & \\
Pemupukan & & \\
P0 & $2.58 \mathrm{c}$ & $16.69 \mathrm{c}$ \\
P1 & $3.47 \mathrm{a}$ & $19.69 \mathrm{a}$ \\
P2 & $3.15 \mathrm{~b}$ & $18.64 \mathrm{~b}$ \\
P3 & $3.56 \mathrm{a}$ & $19.53 \mathrm{ab}$ \\
Konsentrasi ZPT & & \\
Auksin & & \\
R0 & $3.05 \mathrm{~b}$ & 18.56 \\
R1 & $3.12 \mathrm{~b}$ & 18.11 \\
R2 & $3.18 \mathrm{ab}$ & 17.94 \\
R3 & $3.42 \mathrm{a}$ & 19.00 \\
\hline
\end{tabular}

Keterangan : $\mathrm{P} 0=$ tanpa pupuk, $\mathrm{P} 1=1$ Minggu sekali, $\mathrm{P} 2=2$ minggu sekali, $\mathrm{P} 3=3$ minggu sekali, R0 $=0 \mathrm{ppm}, \mathrm{R} 1=75 \mathrm{ppm} \mathrm{R} 2=150$ ppm, R3= 300 ppm. *Simbol yang diikuti huruf yang sama pada masing - masing grafik menunjukkan tidak berbeda nyata pada uji DMRT 5\%

Pengamatan jumlah buku dibutuhkan untuk mengetahui berapa banyak jumlah bibit yang dapat dihasilkan berdasarkan perhitungan jumlah

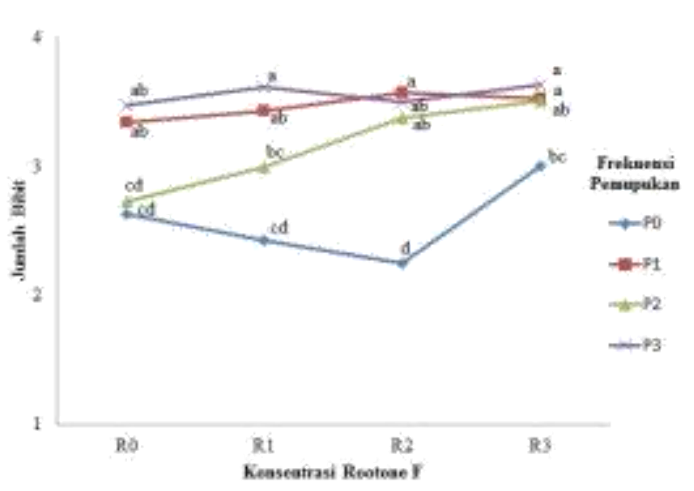

Keterangan : $\mathrm{P} 0=$ tanpa pupuk, $\mathrm{P} 1=1$ Minggu sekali, $\mathrm{P} 2=2$ minggu sekali, $\mathrm{P} 3=3$ minggu sekali, $\mathrm{R} 0=0 \mathrm{ppm}, \mathrm{R} 1=75 \mathrm{ppmR} 2=150$ ppm, R3= 300 ppm. *Simbol yang diikuti huruf yang sama pada masing - masing grafik menunjukkan tidak berbeda nyata pada uji DMRT 5\%

Gambar 3.Interaksi perlakuan konsentrasi ZPT auksindan frekuensi pemupukan terhadap jumlah bibit cabang primer ukuran $15 \mathrm{~cm}$ pada umur setek 56 HST.

buku dari setek ukuran 2 buku, selain itu juga untuk mengetahui panjang antar ruas bibit ubi jalar yang dipanen.

Berdasarkan pengamatan di lapang panjang antar ruas pada cabang primer rata-rata adalah 2.5 $\mathrm{cm}$ dan masih tergolong normal.Hasil rekapitulasi sidik ragam (Tabel 1) menunjukkan bahwatidak ada interakasi yang terjadi antara konsentrasi auksindan frekuensi pemupukan terhadap peubah jumlah buku.Perlakuan konsentrasi ZPT auksin tidak berpengaruh nyata terhadap jumlah buku cabang primer.Jumlah bukuhanya dipengaruhi oleh faktor tunggal frekuensi pemupukan.

Hasil uji lanjut faktor tunggal frekuensi pemupukan pada Tabel 4, dapat diketahui bahwa perlakuan P1 pemupukan 1 minggu sekali menghasilkan jumlah buku tertinggi, baik pada cabang primer maupun cabang sekunder. Perlakuan P1 rata-rata menghasilkan 19.69 buku pada cabang primer dan tidak berbeda nyata dengan perlakuan P3. Sedangkan pada cabang sekunder rata-rata menghasilkan 13.92 buku dan tidak berbeda nyata dengan perlakuan P2. Berdasarkan hasil pengamatan tersebut setek ubi jalar ukuran 2 buku umur 56 HST mampu menghasilkan nilai tertinggi multiplikasi bibit (ukuran 2 buku) dengan perbandingan 1: 9

\section{Multiplikasi Rasio}

Berdasarkan data panjang cabang primer, panen bibit ubi jalar tercepat ukuran $15 \mathrm{~cm}$ dapat dilakukan pada umur 28 HST dengan rata-rata panjang cabang primer $17.89 \mathrm{~cm}$. Produksibibit cabang primer dalam waktu 2 bulan menghasilkan multiplikasi rasio 1:3. Produksi bibit secara konvensional dengan menggunakan 
setek ukuran $15 \mathrm{~cm}$ atau dengan jumlah buku 5 hanya mampu menghasilkan rata-rata 6 bibit (Maulida, 2016).Setek pucuk dengan panjang cabang $20 \mathrm{~cm}$ dan jumlah buku 8 maka dengan teknik perbanyakan cepat setek 2 buku dapat menghasilkan 12bibitukuran $15 \mathrm{cmPanjang}$ ratarata ruas antar buku (internode) cabang primer yaitu $2.5 \mathrm{~cm}$, sehingga panen bibit $15 \mathrm{~cm}$ memiliki jumlah node sebanyak 6 node. Jumlah produksi bibit ukuran $15 \mathrm{~cm}$ dapat ditingkatkan dengan metode transplanting bibit.Transplanting bibit ukuran $15 \mathrm{~cm}$ pada umur 28 HST dengan teknik perbanyakan cepat setek 2 buku dalam waktu 1 bulan mampu menghasilkan 3 bibit ukuran $15 \mathrm{~cm}$. Dalam waktu 2 bulan setek 2 buku mampu menghasilkan 4 bibit.

\section{KESIMPULAN}

Aplikasi ZPT auksin pada setek ubi jalar ukuran 2 bukuberpengaruh terhadap pertumbuhan vegetatif panjang batang dan jumlah daun serta jumlah bibit cabang primer. Pemberian pupuk daun berpengaruh terhadap semua variabel pengamatan.Pemberian pupuk daun meningkatkan jumlah bibit cabang primer ukuran $15 \mathrm{~cm}$. Terdapat interaksi antara konsentrasi ZPT auksindan frekuensi pemupukan terhadap panjang cabang primer umur $28 \mathrm{HST}$, jumlah daun cabang primer umur 28 HST dan 56 HST, jumlah tunas cabang sekunder pasca panen cabang primer, serta jumlah bibit cabang primer ukuran 15 $\mathrm{cm}$.Panen bibit ukuran $15 \mathrm{~cm}$ paling cepat dapat dipanen pada umur 4 MST. Teknik perbanyakan cepat ubi jalar mampu menghasilkan bibit cabang primer ukuran $15 \mathrm{~cm}$ dengan rasio 1:3

\section{DAFTAR PUSTAKA}

[Balitbang] Badan Penelitian dan Pengembangan Pertanian. 2012. Pengelolaan tanaman secara terpadu (PTT) ubi jalar.

Kementrian Pertanian Republik Indonesia.Pusat Penelitian dan Pengembangan Tanaman Pangan, Jakarta.

Bintoro, M.H., Y. Herdiana, S.L. Dalimunthe. 1994. Pengaruh konsentrasi dan selang waktu pemberian pupuk daun agroking 2000 terhadap pertumbuhan setek teh tri 2025 (Camellia sinensis (L) O. Kuanize). Bul. Agron. 22(2):60-65.

[BPS] Badan Pusat Statistik. 2016. Produktivitas Ubi Jalar Menurut Provinsi (kuintal/ha),2006-2015.

http://www.bps.go.id/tnmn_pgn.phpadodb_ next_page $=2 \&$ eng $=0 \&$ pgn $=7 \&$ prov $=99 \& \mathrm{t}$ $\mathrm{hn} 2=2009 \&$ luas $=1 \&$ produktivitas $=1 \&$ produksi $=1$. [2 Desember 2016].

Budianto, M.I., A. Arsyadmunir, Suhartono. 2013. Pertumbuhan stek Cabe Jamu (Piper retrofractum Vahl) pada berbagai campuran media tanam dan konsentrasi zat pengatur tumbuh Auksin. J. Agrovigor. 6 (2): 112-120.

[DIPERTAN] Dinas Pertanian. 2016. Teknik Budidaya Ubi Jalar. Dinas Pertanian Kabupaten Grobogan, Provinsi Jawa Tengah.

http://dinpertangrobogan.000webhostapp.c om/teknik-budidaya-ubi-jalar. $\left[\begin{array}{ll}20 & \text { April }\end{array}\right.$ 2018].

[DISTANTP] Dinas Pertanian Tanaman Pangan. 2012. Juknis Teknik Pengelolaan Ubi Jalar. Dinas Pertanian Tanaman Pangan Provinsi Jawa Barat.

Danu, A.A. Pramono. 2004. Faktor - faktor yang berpengaruh dalam perbanyakan vegetatif. Atlas Benih VI. Balai Litbang Teknologi Perbenihan, Bogor.

[FAO] Food and Agriculture Organization. 2010. Quality declared planting material : protocols and standards for vegetatively propagated crops. FAO Publications, Rome.

Gomez, K.A., A.A. Gomez. 1995. Prosedur Statistik untuk Penelitian Pertanian.Sjamsudin, E., J.S. Baharsjah, penerjemah. Terjemahan dari Statistical Procedures for Agricultural Research. UI Press, Jakarta.

Handayani, M. 2009. Pengaruh dosis pupuk NPK dan kompos terhadap pertumbuhan bibit salam (Eugenia polyantha Wight) [Skripsi]. Institut Pertanian Bogor, Bogor.

Hanafiah, K.A. 2005. Rancangan Percobaan Aplikatif. PT Raja Grafindo Persada, Jakarta.

Harjadi, S.S. 2009. Zat Pengatur Tumbuh. Penebar Swadaya. Jakarta.

Kusumo S. 1984. Zat Pengatur Tumbuh Tanaman. Yasaguna, Bogor.

Latifah, I. 2005. Pengaruh konsentrasi zat pengatur tumbuh IBA dan natrium terhadap viabilitas optimal pada setek vanili (Vanilla planifolia Andrews) [Skripsi]. Universitas Brawijaya, Malang. 
Leiwakabessy, F.M., A. Sutandi. 2004. Pupuk dan Pemupukan. Institut Pertanian Bogor, Bogor.

Lingga, P. 1998. Petunjuk Penggunaan Pupuk. Penebar Swadaya. Jakarta.

Manurung, S.O. 1987. Status dan Potensi Zat Pengatur Tumbuh Serta Penggunaan Auksin Dalam Perbanyakan Tanaman. Makalah Seminar Auksin. Ditjen Reboisasi dan Rehabilitasi Lahan. Dept. Kehutanan, Jakarta.

Maulida, D.P. 2016. Pengaruh jumlah buku terhadap produksi bibit ubi jalar Varietas Cilembu dan Varietas Ungu. Bul. Agrohorti 6(1) : 79 - 87 (2018). Bogor.

Nurholis. 2014. Pertumbuhan bibit panili (Vanilla planifolia Andrews) pada beberapa komposisi media tanam dan frekuensi aplikasi pupuk daun. [Tesis]. Institut Pertanian Bogor. Bogor.

Palemba, T.Y. 2012. Aplikasi pupuk daun Gandasil D terhadap pertumbuhan bibit jabon merah (Anthocephalus macrophyllus Havil) [Skripsi]. Institut Pertanian Bogor, Bogor.

Poerwanto, R., A.D. Susila. 2014. Teknologi Hortikultura. IPB Press, Bogor.

Purnamasari, P. 2013. Pengaruh jarak tanam dan konsentrasi Rootone - F terhadap kecepatan penutupan biomulsa Arachis pintoi Krap. Dan Greg.pada pertanaman Cabai (Capsicum annuum L.) keriting hibrida [Skripsi]. Institut Pertanian Bogor, Bogor.

Puspitaningrum, A. 2014. Perbanyakan cepat pada ubi kayu (Manihot esculenta Crantz.) dengan setek muda. [Skripsi]. Institut Pertanian Bogor, Bogor.

Rukmana, R. 2007. Ubi Jalar Budi Daya dan Pascapanen. Kanisius, Yogyakarta.

Saleh, N., S.A. Rahayuningsih, M.M. Adie. 2012. Peningkatan produksi dan kualitas umbiumbian. Balitkabi, Malang.
Shofiana, A.A. 2015. Aplikasi pupuk daun untuk meningkatkan keragaaan cabai hias dalam pot [Skripsi].Institut Pertanian Bogor, Bogor.

Simatupang, S. 2010. Manajemen pemupukan kelapa sawit (Elaeis guineensis Jacq.) di Perkebunan PT Sari Aditya Loka I (PT. Astra Agro Lestari Tbk) Kabupaten Merangin, Provinsi Jambi [Skripsi]. Institut Pertanian Bogor. Bogor

Steel, R.G.D., J.H. Torrie. 1991. Prinsip dan Prosedur Statistika. Terjemahan B. Sumantri. Gramedia Pustaka Utama, Jakarta.

Suprapto, A. 2004. Auksin : zat pengatur tumbuh penting meningkatkan mutu stek tanaman. J.P. Universitas Tidar, Magelang. Vol. 21 No.1.(11) : 81-90.

Uluputty, M.R. 2015. Pertumbuhan dan hasil seledri (Apium grafeolens L.) pada media pasir setelah diberikan gandasil $\mathrm{d}$ dan atonik. J.Agrologia. Vol. 4 (1): 28-33.

[UNDP] United Nation Development Programe. 2014. Kajian ubi jalar dengan pendekatan rantai nilai dan iklim usaha di Kabupaten Jayawijaya. Program Pembangunan berbasis Masyarakat Fase II : Implementasi Institusional Pembangunan Mata Pencaharian yang Lestari Untuk Masyarakat Papua. UNDP Indonesia dan ILO, Jayawijaya.

Wargiono, J., A. Hasanuddin, Suyamto. 2006. Teknologi Produksi Ubikayu Mendukung Industri Bioethanol. Puslitbangtan, Bogor.

Wargiono J. 2007. Penuntun Bercocok Tanam Ubi Jalar. Buletin Penataran PPS Bidang Agronomi dan Pola Pertanaman. Puslitbangtan Bogor.

Widodo ES, Sudradjat. 1984. Pengaruh naungan dan pemupukan nitrogen terhadap pertumbuhan bibit coklat (Theobroma cacao L.) di persemaian. J Agronomi Indonesia. 94(4): 58-70.

Yin-Tung W. 2007. Potassium nutrition affects Phalaenopsis growth and flowering. Hort Science. 42(7):1563-1567. 